\title{
Stabil Anjina Pektoris ile Başvuran Hastalarda Koroner Yavaş Akımın Klinik ve Laboratuvar Belirleyicileri
}

\section{Clinical and Laboratory Determinants of Coronary Slow Flow in Patients Presenting with Stable Angina Pectoris}

\author{
Songül Usalp ${ }^{1 *}$, Emine Altuntaş ${ }^{1}$, Bayram Bağırtan ${ }^{1}$, Enver Yücel ${ }^{1}$, Ali Bayraktar ${ }^{1}$ \\ ${ }^{1}$ Kardiyoloji Kliniği, Sancaktepe Şehit Profesör Doktor İlhan Varank Eğitim ve Araştırma Hastanesi, İstanbul,
} Türkiye.

e-mail: dr.songulusalp@hotmail.com,emine_altuntas@hotmail.com,bayrambagirtan2@hotmail.com, enveryucel@gmail.com, alibayraktar76@yahoo.com

ORCID: 0000-0001-9572-5431

ORCID: 0000-0001-5887-5422

ORCID: 0000-0001-8136-3820

ORCID: 0000-0002-3654-2448

ORCID: 0000-0001-5219-4087

*Sorumlu yazar/ Corresponding Author: Songül Usalp

Gönderim Tarihi / Received: 05.05.2021

Kabul Tarihi / Accepted: 21.06.2021

DOI: $10.34087 /$ cbusbed. 932932

$\ddot{\mathbf{O} z}$

Giriş ve Amaç: Koroner yatağın gecikmiş kontrast boyanmasıyla tanımlanan koroner yavaş akımın fenomeninin (KYA) patogenezinde endotelyal disfonksiyon olduğu düşünülmektedir. Bu çalışmamızda, stabil anjina pektoris ile başvuran ve yapılan koroner anjiografi sonrası KYA saptanan hastaların genel klinik özelliklerini ve risk faktörlerini bulmayı hedefledik.

Gereç ve Yöntemler: Çalışmaya koroner anjiografi yapılarak KYA tespit edilen 121 hasta ve koroner damarlarında normal akım saptanan 164 hasta olmak üzere, toplam 285 hasta alındı. Bütün hastaların demografik ve klinik özellikleri geriye dönük olarak tarandı ve bu iki grup klinik özellikleri bakımından karşılaştırıldı.

Bulgular: KYA olanların çoğu sigara içen, hipertrigliseridemisi olan ve çoğunlukla erkek cinsiyette olan hastalardı. Biyokimyasal parametreler, elektrokardiyografik ve ekokardiyografik özellikler açısından her iki grup arasında anlamlı farklılık izlenmedi. Çok değişkenli regresyon analizlerinde erkek cinsiyet (olasılık oranı [OO]:0.434, \%95 güven aralığ $:[0.252-0.856], \mathrm{p}=0.014)$ ve hipertrigliseridemi $(\mathrm{OO}: 1.001, \% 95$ güven aralı̆̆ $:[1.001-1.007], \mathrm{p}=$ $0.035)$, KYA için bağımsız birer risk faktörü olarak saptandı.

Sonuç: KYA, sigara içen, trigliserid değerleri yüksek ve erkek hastalarda daha sık idi. Erkek cinsiyet ve trigliserit yüksekliği KYA için bağımsız bir faktörü olarak bulundu. Trigliserid düzeyinin tahmini kesim değerinin > 138.5 $\mathrm{mg} / \mathrm{dL}$ olması KYA ile ilișkili bulundu.

Anahtar kelimeler: Koroner yavaş akım, hiperlipidemi, erkek cinsiyet

\footnotetext{
Abstract

Objective: Endothelial dysfunction is thought to be involved in the pathogenesis of coronary slow flow phenomenon (CSFP) defined which is an angiographic phenomenon characterised by the slow passage of contrast in the absence of obstructive coronary artery disease. In this study, we aimed to find the clinical characteristics and risk factors of patients with CSFP after coronary angiography in those presenting with stable angina pectoris.

Materials and Methods: A total of 285 patients were included in the study, 121 of whom were diagnosed with CSFP and 164 patients with normal flow on coronary angiography. In this study, we aimed to find the clinical characteristics and risk factors of patients with CSFP after coronary angiography in patients presenting with stable angina pectoris
} 
Results: Most of the patients with CSFP were smokers, having hypertriglyceridemia, and mostly male gender. There was no significant difference between the two groups in terms of biochemical parameters, electrocardiographic and echocardiographic characteristics. In multivariate regression analyzes, male gender (odds ratio [OO]:0.434, 95\% confidence interval: [0.252-0.856], $\mathrm{p}=0.014)$ and hypertriglyceridemia $(00: 1.001,95 \%$ confidence interval [1.001 - 1.007], $\mathrm{p}=0.035$ ) were found to be independent risk factors for CSFP.

Conclusion: CSFP was more common in smoker male patients and those that had high triglyceride levels. Male gender and high triglyceride levels were found to be an independent risk factor for CSFP. A cut-off value >138.5 $\mathrm{mg} / \mathrm{dL}$ of serum triglyceride level was found to be associated with CSFP.

Keywords: Coronary slow flow, hyperlipidemia, male gender

\section{Giriş}

Koroner yavaş akım (KYA), anjiografi sırasında tespit edilen ve koroner damar yatağının gecikmiş boyanmasıyla karakterize bir fenomendir [1]. Koroner yavaş akımda, mikrovasküler düzeyde endotel disfonksiyonundan inflamasyona ve ateroskleroza kadar birçok faktörün patogenezde rol oynadığ 1 düşünülmektedir. Toplumda görülme sıklığı \%1-7 arasındadır [2]. Hastalar, çoğunlukla iyi prognoza sahip olsa da, kronik ve sık olan anjina atakları yaşam kalitesini bozabilir. KYA'lı hastalarda, elektrokardiyografik değişiklikler, malign ventriküler aritmi, kardiyak arrest ile sonuçlanan vaka bildirimleri bulunmaktadir [3].

Koroner yavaş akımda meydana gelen endotel disfonksiyonuyla ilişkili olarak çeşitli moleküller suçlanmıştır [3]. İnflamatuar hastalıklarda düzeyi artan $\mathrm{C}$ reaktif proteinin (CRP), albumine oranı (CAR), homosistein düzeyi, tiroid hormon salınımının bozuklukları, interlökinler gibi mediyatörlerin koroner yavaş akımda arttığı savunulmuştur [2,3,4,5]. Sadece biyokimyasal bulgularda değil, aynı zamanda elektrokardiyografide PR mesafesinin uzadığ QRS-T açısının arttı̆̆ı gösterilmiştir [6].

Geçmişe yönelik literatür taraması yapıldığında, inflamasyon parametrelerinin KYA'da arttığı yönünde yayınlar çoğunlukta olmakla beraber, çelişkili sonuçlar bulunmaktadır ve bu yayınlar çoğunlukla düşük hasta popülasyonu ile sinırlıdır. Biz bu çalışmamızda, ilk defa birçok parametreyi bir arada ele alarak, koroner yavaş akımda risk faktörü olabilecek klinik parametreleri bulmayı hedefledik.

\section{Materyal ve Metot}

Hastanemize, 2019 Ocak-2021 Ocak göğüs ağrıs1 ile başvuran stabil angina pektoris tanısı alan toplam 285 hasta alındı. Çalışma geriye dönük, gözlemsel bir çalışma olup, bütün hastaların ayrıntılı tıbbi öyküleri, kan tetkikleri ve demografik özellikleri medikal kayıtlarından alındı. Vücut kitle indeksleri, kilogramlarının, boylarına karesinin oranı ile hesapland 1 (kg/m2). Çalışmaya alınan ve yapılan koroner anjiografilerinde \% 40 veya daha az altında darlık saptanan hastalar iki gruba ayrıldı: Epikardial koroner arterlerin en az birinde yavaş akım saptananlar $(n=121)$ ve koroner kan akımı normal saptananlar $(n=164)$. Bu iki grup arasında, demografik özellikleri, elektrokardiyografi, ekokardiyografi ve laboratuar bulguları açısından karşılaştırma yapıldı.
Elektrokardiyografiler, iki bağımsız kardiyolog tarafindan incelendi.

Dışlanma kriterleri: Koroner arterlerde \% 40' in üzerinde darlık olması, konjenital kalp hastalıkları, koroner arterlerde ektazi, koroner vazospazm tanısı alanlar, hipertrofik kardiyomiyopatisi olanlar, ileri kalp kapağı yetersizliği veya darlığı, kalp, böbrek ve karaciğer yetmezliği, malignitesi olanlar, troid hastalığı nedeniyle tedavi olanlar çalışmaya dahil edilmedi.

$\mathrm{Bu}$ çalışma için etik kurul onayı, çalışmanın yapıldığ 1 merkezden alınmıştır (Etik kurul onay tarihi: 21. 04. 2021, Etik kurul onay numaras1:2021/144)

2.1.Koroner yavaş akımın anjiografik olarak tanimlanmasl

Koroner anjiografi, tüm hastalara femoral yoldan standart Judkins tekniği ile yapıldı. Anjiografi esnasinda kontrast madde olarak Iohexol (Omnipaque 350, GE Healthcare) kullanıld1. Standart koroner anjiografi görüntüleri aynı cihazdan görüntülendi. Anjiografi esnasında koroner akımı etkileyebilecek herhangibir ilaç verilmedi. Her pozda 6-8 ml kontrast ajan manuel verildi. Koroner yavaş akım tanısı konulurken, miyokard infarktüsünde tromboliz (TIMI) frame count yöntemi kullanıldı [7]. Bu yöntemde, sol ön inen koroner arterin distal ucuna kontrast maddenin ulaşması için gerekli "sineframe" sayısı olarak kabul edilir. Kontrast maddenin koroner artere girdiği frame, ilk frame olarak kabul edilir. Daha sonra ilk ve son frame arasındaki fark alınarak, TIMI frame (TFC) sayısı olarak hesaplanır. LAD uzun olduğu için TFC değeri 1.7' ye bölünerek düzeltilmiş TFC hesaplanır. LAD'in düzeltilmiş TFC' si CX ve RCA nın TFC değerleri toplanıp 3'e bölünerek ortalama TFC hesaplanır. LAD için düzeltilmiş TFC 21.9 \pm 3.5 kare, CX için $21.3 \pm 3.7$ kare, RCA için $20.2 \pm 3.2$ kare normal kabul edildi. Normal değerlerin 2 standart sapma üstündeki değerler koroner yavaş akım olarak kabul edildi [7].

Koroner anjiografi görüntüleri ve TIMI Frame Count (TFC) sayımı 2 farklı ve birbirinden bağımsız kardiyolog tarafindan yorumlandı. Yorumlar farklı olduğu takdirde, üçüncü bir kardiyoloğun görüşü alınd1.

2.2.Elektrokardiyografik ve ekokardiyografik analiz

Tüm hastalar sirtüstü yatar pozisyonda $25 \mathrm{~mm} / \mathrm{ms}$ ve $10 \mathrm{mV} / \mathrm{sn}$ hızında 12 derivasyonlu yüzey elektrokardiyografi (EKG) kaydı alındı (GE Marquette Mac 1200. GE Healthcare 3000 North Grandview Waukesha, WI 53188 USA). Frontal QRS-T açısı, 
QRS ile T dalgası vektörlerinin mutlak farkı şeklinde hesaplandi.

Ekokardiyografik incelemeler, sol yan yatar pozisyonunda Vivid 7 Pro ultrason görüntüleme sistemi (GE Vingmed, Milwaukee, Wisconsin, USA) kullanılarak yapıldı. Konvansiyonel Doppler ekokardiyografi incelemeleri ve M-mod ölçümleri Amerikan Ekokardiyografi Derneği tarafindan yayınlanan standartlara göre yapıldı. Sol ventrikül ejeksiyon fraksiyonu (SVEF) Simpson'ın kuralına göre hesapland1 [8].

\subsection{Istatiksel analizler}

Elde edilen veriler SPSS 20.0 versiyonu (Statistical Package for Social Sciences, Inc., Chicago, IL,USA) istatistik programına kaydedildi. Verilerin normal dağılıma uygun olup olamdığ testi ile değerlendirildi. Normal dağılım gösteren sayısal değişkenler ortalama \pm standart sapma olarak kategorik değişkenler yüzde (\%) olarak ifade edildi. Normal dağılım gösteren veriler iki grup arasında karşıllaştırılırken Students t-test, kategorik değişkenlerin karşılaştırılırken Ki-Kare testi kullanıldı. Normal dağılım göstermeyen veriler ise median (minimum- maximum) değerleri ile ifade edildi ve Mann-Whitney $U$ testi ile karşılaştırıldı. Koroner yavaş akımın, bağımsız öngördürücülerini belirlemek için tek ve çok değişkenli lojistik regresyon analizleri kullanıldı. Hipertrigliserideminin öngördürücü kestirim noktasını belirleyebilmek için, alıcı işletim karakteristik eğri analizi (ROC) kullanıldı. Tüm sonuçlarda $\mathrm{p}<0.05$ değeri anlamlı kabul edildi.

\section{Bulgular ve Tartışma}

\subsection{Bulgular}

Çalışmaya alınan KYA'li hastaların ortalama yaşı $(55.4 \pm 10.1$ y1l), kontrol grubunun ise $(54.5 \pm 11.5$ y11) idi. KYA hastaları ile kontrol grubunun demografik ve klinik özellikleri Tablo 1'de gösterilmiştir. Her iki grup arasında, diyabet, hipertansiyon, hipotroidizim gibi klinik özellikler açısından bir fark bulunmadı. Laboratuar bulgularına gelince, kan şekerleri, serum kreatinin düzeyleri, ürik asit, troid stimüle edici hormon düzeyleri, serum total kolesterol, düşük dansiteli lipoprotein (LDL), yülsek dansiteli lipoprotein (HDL) değerleri, CRP, albumin, CAR, serum vitamin $\mathrm{B} 12$ ve Vitamin $\mathrm{D}$ düzeyleri açısından her iki grup benzerdi (Tablo 1).

Tablo 1. Koroner yavaş akım olan hastalar ile kontrol grubunun demografik, klinik özelliklerinin karşılaştırılması

\begin{tabular}{|c|c|c|c|}
\hline Değişkenler & KYA grubu $(n=121)$ & Kontrol grubu $(n=164)$ & p-değeri \\
\hline Yaş (yll) & $55.4 \pm 10.1$ & $54.5 \pm 11.5$ & 0.498 \\
\hline Erkek cinsiyet, n (\%) & $59(48.8)$ & $44(26.8)$ & 0.001 \\
\hline VKI $\left(\mathrm{kg} / \mathrm{m}^{2}\right)$ & $28.2 \pm 4.7$ & $29.2 \pm 5.5$ & 0.447 \\
\hline Hipertansiyon, n (\%) & $61(56.0)$ & $69(49.3)$ & 0.179 \\
\hline Diyabetes mellitus,n (\%) & $43(41.7)$ & $43(31.2)$ & 0.059 \\
\hline Sigara içiciliği, n (\%) & $52(42.9)$ & $28(17.0)$ & 0.031 \\
\hline Subklinik hipotroidizim (\%) & $17(14.4)$ & $16(9.9)$ & 0.165 \\
\hline Glukoz (mg/dL) & $121.8 \pm 45.6$ & $115.2 \pm 45.8$ & 0.221 \\
\hline Kreatinin (mg/dL) & $0.8 \pm 0.2$ & $0.7 \pm 0.2$ & 0.051 \\
\hline Total kolesterol (mg/dL) & $200.7 \pm 41.6$ & $197.6 \pm 49.1$ & 0.570 \\
\hline LDL-K (mg/dL) & $123.2 \pm 38.9$ & $121.8 \pm 41.5$ & 0.781 \\
\hline HDL-K (mg/dL) & $44.6 \pm 12.6$ & $47.6 \pm 13.8$ & 0.067 \\
\hline Trigliserit (mg/dL) & $188.7 \pm 126.3$ & $146.2 \pm 74.2$ & 0.001 \\
\hline Vitamin B12 (pg/mL) & $300.7 \pm 130.6$ & $311.4 \pm 170.5$ & 0.645 \\
\hline Vitamin D (ng/mL) & $17.6 \pm 9.2$ & $16.2 \pm 9.9$ & 0.433 \\
\hline TSH (mlU/L) & $2.1 \pm 1.9$ & $1.9 \pm 2.5$ & 0.417 \\
\hline Ürik asit (mg/dL) & $5.1 \pm 1.6$ & $4.8 \pm 1.2$ & 0.079 \\
\hline C-reaktif protein (mg/dL) (IQR) & $0.2(0.01-3.8)$ & $0.2(0.01-4.1)$ & $0.863^{*}$ \\
\hline Albumin (mg/dL) & $4.2 \pm 0.5$ & $4.3 \pm 0.3$ & 0.490 \\
\hline CAR (IQR) & $0.05(0.01-0.09)$ & $0.05(0.01-1.0)$ & $0.914 *$ \\
\hline
\end{tabular}

Kısaltmalar: VKI: Vücut kitle indexi, CAR: C-reaktif protein/albumine oranı, KYA:Koroner yavaş akım, HDL: Yüksek yoğunluklu lipoprotein, LDL: Düşük yoğunluklu lipoprotein, n: hasta sayısı, TSH: Tiroid sitümulan hormon. *: Mann-Whitney U test 
KYA grubundaki erkek hasta oranı (\%48.8), kontrol grubuna $(\% 26.8)$ göre daha fazla idi $(p=0.001)$. Aynı zamanda, koroner yavaş akım olanlarda sigara içme oranı daha fazla idi $(\% 42,9$ vs $\% 17.0, p=0.031)$ (Tablo 1). Aynı zamanda, trigliserit değerleri KYA' ${ }_{1}$ hastalarda, anlamlı olarak daha yüksek idi (188.7 \pm 126.3 vs $146.2 \pm 74.2, \mathrm{p}=0.001)$ (Tablo 1$)$
Ekokardiyografik olarak olarak, sol ventrikül ejeksiyon fraksiyonları ve sistolik pulmoner arter basinc1 ve elektrokardiyografik parametreler karşılaştırıldığında, her iki grup arasında anlamlı farklılık izlenmedi (Tablo 2). TIMI kare sayımları, KYA hastalarında anlamlı şekilde yüksek idi (Tablo 2).

Tablo 2. Koroner yavaş akım olan hastalar ile kontrol grubunun elektrokardiyografik ve ekokardiyografik parametreler açısından karşılaştırılması

\begin{tabular}{|c|c|c|c|}
\hline Değişkenler & KYA grubu $(n=121)$ & Kontrol grubu $(n=164)$ & p-değeri \\
\hline SVEF (\%) & $58.8 \pm 5.2$ & $59.9 \pm 3.3$ & 0.052 \\
\hline SPAB (mmHg) & $25.9 \pm 4.9$ & $24.1 \pm 2.6$ & 0.063 \\
\hline \multicolumn{4}{|l|}{ EKG parametreleri } \\
\hline Kalp hızı (dk/atım) & $78.9 \pm 13.4$ & $79.7 \pm 13.6$ & 0.768 \\
\hline PR aralığ $(\mathrm{ms})$ & $145.3 \pm 26.2$ & $139.7 \pm 25.0$ & 0.349 \\
\hline QRS süresi (ms) & $95.9 \pm 18.7$ & $89.7 \pm 20.4$ & 0.179 \\
\hline QT $\operatorname{aralığ} 1(\mathrm{~ms})$ & $377.8 \pm 34.2$ & $371.9 \pm 32.6$ & 0.451 \\
\hline cQT aralığ $1(\mathrm{~ms})$ & $428.7 \pm 40.2$ & $425.7 \pm 27.2$ & 0.705 \\
\hline Frontal QRS-T açısı $\left({ }^{0}\right)$ & $44.7 \pm 43.1$ & $30.1 \pm 29.9$ & 0.087 \\
\hline \multicolumn{4}{|l|}{ TIMI kare sayımları $(*)$} \\
\hline Sol anterior inen arter & $46.5 \pm 13.2$ & $23.4 \pm 4.5$ & $<0.001$ \\
\hline Sirkumfleks arter & $41.7 \pm 12.4$ & $20.5 \pm 3.9$ & $<0.001$ \\
\hline Sağ koroner arter & $36.8 \pm 12.7$ & $20.8 \pm 3.1$ & $<0.001$ \\
\hline
\end{tabular}

Kısaltmalar: dk/atm: Dakikadaki kalp atımı, KYA: Koroner yavaş akım, EKG: Elektokardiyografi, SVEF: Sol ventrikül ejeksiyon fraksiyonu, SPAB: Sistolik pulmoner arter basınc1, TIMI: (*): TFC: Tromboliz çerçeve sayımı.

Tek değişkenli regresyon analizlerinde, erkek cinsiyet (olasılık oranı(OO): $0.676, \% 95$ güven aralı̆̆ı (GA) [0.458 - 0.773], p <0.001), sigara içme (OO : 0.642, $95 \%$ GA $[0.433-0.896], \quad p=0.035)$, ve trigliserit düzeyi yüksekliği (OO : 1.020, \%95 GA [1.002 1.027], $\mathrm{p}=0.001)$, KYA için potansiyel risk faktörleri olarak saptanırken, çok değişkenli regresyon analizlerinde, sadece erkek cinsiyet (OO : $0.434, \% 95$ GA $[0.252-0.856], \quad p=0.014)$, ve trigliserit yüksekliği OO : 1.001, \%95 GA [1.001 - 1.007], p = $0.035)$, KYA için bağımsız birer risk faktörü olarak bulundu (Tablo 3 ).

Tablo 3. Koroner yavaş akım ile, cinsiyet, sigara ve trigliserit arasındaki ilişkiyi gösteren regresyon analizlerinin verileri

\begin{tabular}{|l|l|l|l|l|}
\hline Değişkenler & \multicolumn{2}{|l|}{ Tek değişkenli regresyon analizleri } & \multicolumn{2}{l|}{ Çok değişkenli regresyon analizleri } \\
\hline & RO (\% 95 GA) & p-değeri & RO ( \%95 GA ) & p-değeri \\
\hline Erkek cinsiyet & $0.676(0.458-0.773)$ & $<\mathbf{0 . 0 0 1 *}$ & $0.434(0.252-0.856)$ & $\mathbf{0 . 0 1 4}$ \\
\hline Sigara içiciliği & $0.642(0.433-0.896)$ & $\mathbf{0 . 0 3 5} *$ & $0.412(0.174-1.318)$ & 0.154 \\
\hline Hipertrigliseridemi & $1.020(1.002-1.027)$ & $\mathbf{0 . 0 0 1}$ & $1.001(1.001-1.007)$ & $\mathbf{0 . 0 3 5}$ \\
\hline
\end{tabular}

RO: Risk oranı, GA: Güven aralığı, *: Pearson's Chi-Square

KYA öngörmede yapılan alıcı ișletim karakteristik eğrisi analizinde (ROC), trigliserit için $138.5 \mathrm{mg} / \mathrm{dL}$ eşik değerinin, \%56 duyarlılık ve \%57 özgüllüğe sahip olduğu bulundu (eğri altında kalan alan: 0.59, \%95 GA [0.525-0.663], $\mathrm{p}=0.008)$. 


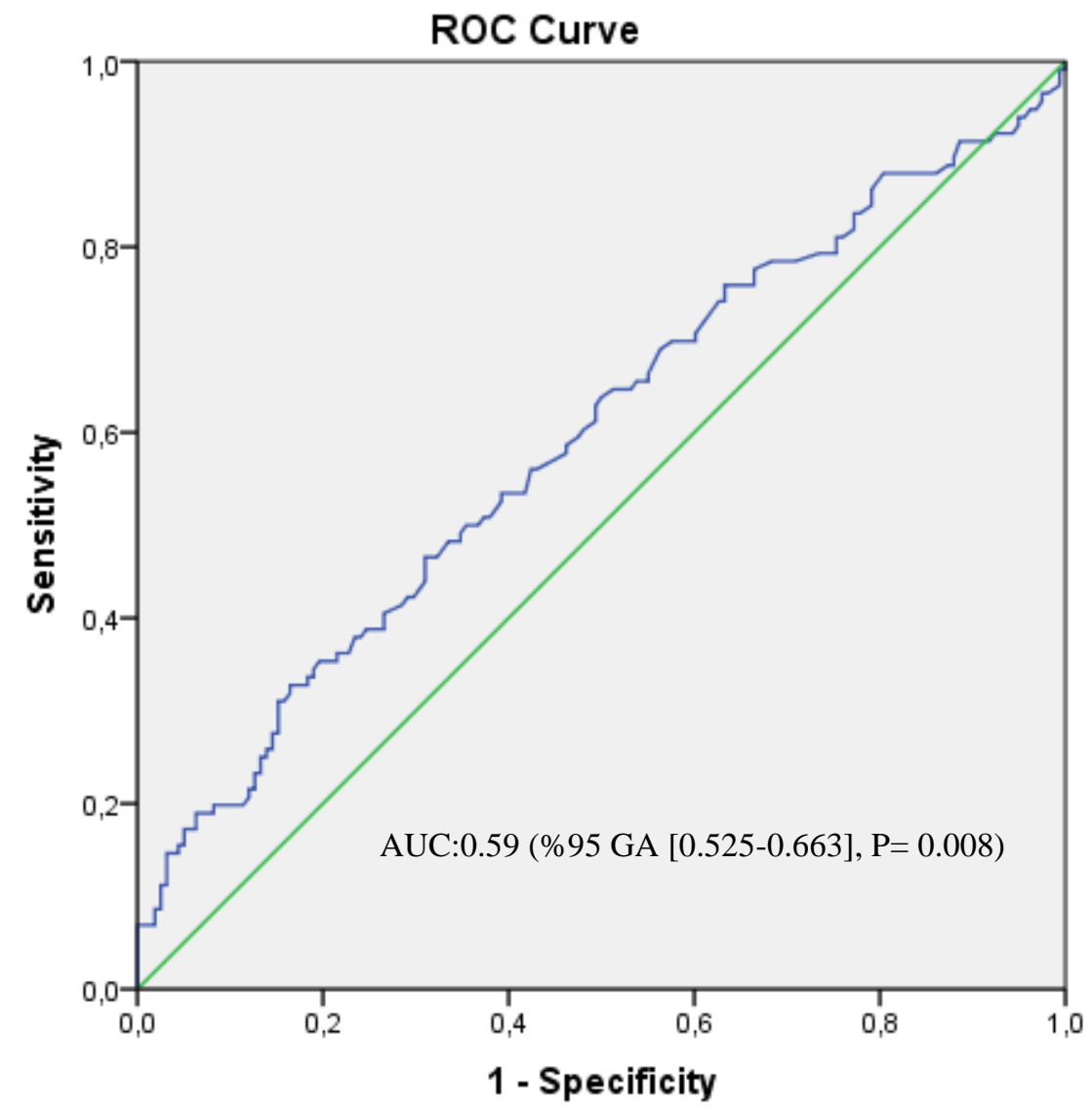

Şekil 1. Alıcı işletim istatistikleri eğrisi (ROC) ile, koroner yavaş akım için, trigliserit düzeyinin kestirim noktası > $138.5 \mathrm{mg} / \mathrm{dL}, \% 56$ duyarlılık, $\% 57$ özgüllük ve eğri altında kalan alan (AUC) 0.59 (\%95 GA [0.525-0.663], p = 0.008) olarak bulundu.

\subsection{Tartışma}

Çalışmamızda, koroner yavaş akımı olan hastaların ağırlıklı olarak, sigara içen, trigliserit düzeyleri yüksek ve erkek cinsiyette oldukları görüldü. Hatta, erkek cinsiyet ve hipertrigliserideminin KYA için bağımsız birer faktörü olduğunu bulduk. İnflamasyonla ilişkili olabilecek laboratuvar parametreleri ile ekokardiyografi ve elektrokardiyografik özellikler açısından her iki grup arasında fark saptanmadi.

Koroner yavaş akımın mekanizması henüz tam olarak anlaşılamamış olsa da, endotel disfonksiyonu, trombosit disfonksiyonu, oksidative stres, vasomotor disfonksiyon, sistemik /lokal inflamasyon ve/veya tüm bunların kombinasyonunun direkt ve ya indirekt olarak patogenezde rol oynadığı düşünülmektedir $[1,2]$. İnflamasyonda artış gösteren parametrelerden biri olan yüksek duyarlıklı CRP, kardiyovasküler olaylarda da yükselmekte ve aterosklerozun hızlanmasıyla beraber kardiyovasküler mortalite artmaktadır [9]. CRP yükselince, endotel bağımlı vasodilatasyon ve endotelyal stem hücre adhezyonu bozulur ve endotelyal disfonksiyona zemin hazırlanır. Yapılan çalışmalar göstermiştir ki, CRP, fibrinojen/albumin ve CRP/albumin gibi inflamasyon belirteçleri bu hastalarda yüksek saptanmıştır $[9,10]$. bulunamamıştır [14,15]. Bizim çalışmamızda da, KYA olan ve olmayan gruplar arasında, serum tiroit
Düşük serum albumin düzeylerinin kardiyovasküler mortalite ve morbiditie ile yakından ilişkili olduğuna dair yayınlar bulunmaktadır [11].

Şu ana kadar ki birçok çalışmada gösterildiğinin aksine, bizim çalışmamızda, CAR oranı, KYA olan ve olmayanlar arasinda benzer bulundu. Böyle bir sonucun nedeni, belki de hem KYA hem de kontrol grubundaki hastaların çoğunun stabil anjina pektoris ile başvurması ve belki de bu nedenle inflamasyonun yeteri kadar oluşmamıș olması olabilir.

KYA'da, entotel disfonksiyonu ile ilişkilendirilen moleküllerden biri de tiroid hormonlarıdır. Hipotroidizimde, endotelden salgllanan nitrik oksidin azalması, vasküler düz kas gevşemesinde bozulmaya, dolaysıyla arteryel sertliğin artmasına neden olur, kolesterol metabolizmasında bozulmalar görülebilir ve ateroskleroza gidiş hızlanabilir [12]. Jaskanwal ve arkadaşları, hipotroidik hastalarda koroner kan akımı farkının daha düşük olduğunu, özellikle kadın hipotiroidik hastalar ile endotelyal disfonksiyon arasında anlamlı bir ilişki olduğunu bulmuşlardır [13]. Koroner yavaş akımda endotel disfonksiyonu ile tiroid hormonları arasındaki ilişkiyi araştıran iki ayrı çalışmada, koroner yavaş akımı olanlar ve olmayanlar arasında serum TSH düzeyleri arasında anlamlı fark hormonları ve subklinik hipotroidi açısından her iki grup arasında herhangibir anlamlı fark izlenmedi. 
Frontal QRS-T açısı, kalbin depolarizasyon ve repolarizasyon yönünü gösteren vektörler arasındaki açının mutlak farkı olarak tanımlanır ve bu açının artmasının kötü prognozla ve kardiyovasküler hastalıklarla ilişkilendirildiği bir çok çalışma bulunmaktadır [16]. KYA'1 bulunan 60 hastanın değerlendirildiği bir çalışmada, frontal QRS-T açısı KYA'lı hastalarda daha yüksek saptanmış (ortalama 69 derece) [6]. Bizim çalışmamızda ise, her iki grup arasında anlamlı farklılık bulunmamakla beraber, yine de, frontal QRS-T açısı ortalaması, KYA olanlarda daha yüksek idi (44.7'e karşın 30.1 derece). KYA grubundaki hastalarımızın hipertansiyon ve diyabet dışında önemli hastalıklarının olmaması ve kalp fonksiyonlarının normal sınırlarda olması böyle bir sonuç elde etmemize neden olmuş olabilir.

Hipertrigliseridemi, metabolik sendromun da bir komponenti olup, HDL' nin ateroprotektif ve antiinflamatuvar etkilerini baskılayabilirler, ayrıca bunların endotele bağlı koroner vazodilatasyon bozukluğu ile anlamlı derecede ilişkili olduğu gösterilmiştir [17]. Trigliseritler, arterlerin endotelinde depolanabilirler ve aterosklerotik plağın olduğu intima duvarına girebilirler. Burda, sitokin salınımını arttırarak, inflamasyona neden olabilir ve aterosklerozu hizlandırabilirler [17]. Dolaysıyla, trigliseritlerin endotelyal disfonksiyona neden oldukları bazı çalışmalarda gösterilmiştir [18]. KYA olan hastalarda yapılan bir çok çalışmaların çoğunda, bu hastaların sıklıkla erkek cinsiyette olan, sigara içen ve hipertrigliseridemisi olan hastalar oldukları saptanmış [19,20,21]. Çalışmamızda da, literatür ile uyumlu olarak, KYA olan hastaların çoğunlukla, sigara içen, hipertrigliseridemisi olan ve erkek cinsiyette oldukları görüldü.

\section{Çalışmanın kısıtlılıkları}

Çalışmamıza alınan hasta sayısı stabil anjina pektorisli hastaları kapsayan tek merkezli bir çalışma idi. Hastanemiz laboratuarlarında çalışılabilen belli bazı inflamasyon belirteçleri bakılabilmiştir. $\mathrm{Bu}$ nedenle, hem hasta sayısının arttırılması, hem geniş biyokimyasal belirteçlerin çalışılması, ileriki çalışmalarda düşünülebilinir.

\section{Sonuç}

Çalışmamızda, sigara içen, hipertrigliseridemisi olan ve erkek cinsiyet olan hastaların KYA ile ilişkili olduğunu bulduk. İnflamasyonu gösteren bir çok parametrenin KYA olanlarda anlamlı artmadığ görüldü. İlerde yapılacak daha büyük çaptaki ve geniş biyokimyasal belirteçlerin ilave edileceği büyük çalışmalar bu konuya 1şık tutabilir.

\section{Referanslar}

1.Wang, X, Nie, S.P, The coronary slow flow phenomen: characteristics, mechanism and implications, Cardiovascular Diagnosis. Therapy, 2011, 1(1), 37-43.

2. Wang, X, Geng, L.L, Nie, S.P, Coronary slow flow phenomenon: a local or systemic disease? Medical Hypotheses, 2010, 75(3), 334-337.

3. Amasyali, B, Turhan, H, Kose, S, et al., Aborted sudden cardiac death in a 20-year-old man with slow coronary flow, International Journal of Cardiology, 2006, 109(3), 427-429.
4.Slevin, M, Krupinski, J, A role of C-reactive protein in the regulation of angiogenesis, endothelial cell inflammation and thrombus formation in cardiovascular disease, Histology and Histopathology, 2009, 24(11), 1473-8.

5.Li, J.J, Qin, X.W, Li, Z.C, et al., Increased plasma C-reactive protein and interleukin-6 concentrations in patients with slow coronary flow, Clinica Chimica Acta, 2007, 385(1-2), 43-47.

6.M.S, Kuyumcu, Özbay, M.B, Özen, Y, et al., Evaluation of frontal QRS-T angle in patients with slow coronary flow, Scandinavian Cardiovascular Journal, 2020, 54(1), 20-25.

7.Gibson, C.M, Cannon, C.P, Daley, W.L, et al, for the TIMI 4 Study Group: TIMI frame count: a quantitative method of assessing coronary artery flow, Circulation, 1996, 93(5), 879888.

8. Mitchell, C, Rahko, S, Blauwet, L.A, et al., Guidelines for Performing a Comprehensive Transthoracic Echocardiographic Examination in adults: Recommendation from the American Society of Echocardiography, Journal of American Society of Echocardiography, 2019, 32(1), 1-64.

9. Yesin, M, Çağdaş, Karabağ, Y, et al., Assessment of the relationship between $\mathrm{C}$-reactive protein-to-albumin ratio and slow coronary flow in patients with stable angina pectoris, Coronary artery disease, 2019, 30(7), 505-510.

10. Kayapinar, O, Ozde, C, Kaya, A, Relationship Between the Reciprocal Change in Inflammation-Related Biomarkers (Fibrinogen-to-Albumin and hsCRP-to-Albumin Ratios) and the Presence and Severity ofCoronary Slow Flow, Clinical and Applied Thrombosis Hemostasis, 2019, 25, 1076029619835383.

11. Phillips, A, Shaper, A.G, Whincup, P.H, Association between serum albumin and mortality from cardiovascular disease, cancer, and other causes, Lancet,. 1989, 2(8677), 1434-1436.

12. Udovcic, M, Pena, R.H, Patham, B, et al., Hypothyroidism and Heart, Methodist Debakey Cardiovascular Journal, 2017, 13(2), 55-59.

13. Sara, J.D, Zhang, M, Gharib, H, et al., Hypothyroidism Is Associated With Coronary Endothelial Dysfunction in Women, Journal of the American Heart Association, 2015, 29(8), e002225.

14. Evrengül, H, Tanrıverdi, H, Enli, Y, et al., Interaction of Plasma Homocysteine and Thyroid Hormone Concentrations in the Pathogenesis of the Slow Coronary Flow Phenomenon. Cardiology, 2007, 108(3), 186-192.

15. Madak, N, Nazlı, Y, Mergen, H, et al., Acute phase reactants in patients with coronary slow flow phenomenon, Anadolu Kardiyol Dergisi, 2010, 10(5), 416-420.

16. Oehler, A, Feldman, T, Henrikson, C.A, Tereshcenko, L.G, QRS$\mathrm{T}$ angle: a review, Annals of Noninvasive Electrocardiology, 2014, 19(6), 534-542.

17. Peng, J, Luo, F, Ruan, G, et al., Hypertriglyceridemia and atherosclerosis, Lipids Health Disease, 2017, 16(1), 233.

18. Lucero D, Lopez, G.I, Gorzalczany, S, et al., Alterations in triglyceride rich lipoproteins are related to endothelial dysfunction in metabolic syndrome, Clinical Biochemistry, 2016, 49(12), 932-935.

19. Zhu, X, Shen, H, Gao, F, et al., Clinical Profile and Outcome in Patients with Coronary Slow Flow Phenomenon, Cardiology research and practise, 2019, 9168153

20. Ghaffari, S, Tajlil, A, Aslanabadi, N, et al., Clinical and laboratory predictors of coronary slow flow in coronary angiography, Perfusion, 2017, 32(1), 13-19.

21. Sanghvi, S, Mathur, R, Baroopal, A, et al., Clinical, demographic, risk factor and angiographic profile of coronary slow flow phenomenon: A single centre experience, Indian Heart Journal, 2018, 70(3), 290-294.

http://edergi.cbu.edu.tr/ojs/index.php/cbusbed isimli yazarın CBU-SBED başlıklı eseri bu Creative Commons Alıntı-Gayriticari4.0 Uluslararası Lisansı ile lisanslanmıştır.

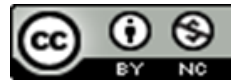

